\title{
Methods for Estimating Concentrations and Loads of Selected Constituents in Tributaries to Lake Houston near Houston, Texas
}

\author{
Background \\ Houston, Texas, is the fourth largest city in the United States, with an estimated population of about 5.9 million people \\ in 2009 (Texas State Data Center, 2011). Historically, groundwater has been the major source of supply for the City of \\ Houston; however, development of groundwater resources has contributed to water-level declines and land-surface subsidence \\ (Kasmarek and others, 2010). Lake Houston is a surface-water-supply reservoir for the City of Houston and currently (2011) \\ supplies between 10 and 20 percent of the total source-water supply (City of Houston, 2011). As a result of regulations \\ restricting groundwater withdrawals for the purpose of mitigating or arresting land-surface subsidence, Lake Houston is \\ expected to become the primary source of water for the city in the future; the overall goal is to increase the use of surface \\ water to no less than 80 percent of the total demand by 2030 (Harris-Galveston Subsidence District, 1999). Because Lake \\ Houston is both a major source of potable water and a recreational resource for the Houston area, the possible effects of \\ urbanization on the water quality of tributaries to Lake Houston are of interest to water managers and planners and require a \\ comprehensive understanding of the factors that affect this environment.
}

\section{Data Collection}

Since December 2005, the U.S. Geological Survey (USGS), in cooperation with the City of Houston, Tex., has been assessing the quality of the water flowing into Lake Houston. Continuous in-stream water-quality monitors were installed at two USGS streamflow-gaging stations that represent watersheds contributing to Lake Houston (fig. 1) to provide real-time measurements of streamflow and other physical waterquality properties. USGS streamflow-gaging station 08068500 Spring Creek near Spring, Tex., is in a primarily urban watershed, whereas USGS streamflow-gaging station 08070200 East Fork San Jacinto River near New Caney, Tex., is in a primarily rural watershed. The watersheds of Spring Creek and East Fork San Jacinto River represent approximately 31 percent of the drainage area to Lake Houston. Additionally, discrete water-quality samples are periodically collected on these tributaries and analyzed for selected constituents of concern. For this analysis, 58 samples were collected at the Spring Creek site, and 51 samples were collected at the East Fork San Jacinto River site. Hydrologic conditions in the Spring Creek and East Fork San Jacinto River sites vary and might affect chemical constituent concentrations, so discrete water-quality samples were collected over a wide range of streamflow conditions (fig. 2). All samples were collected and processed as outlined in the USGS "National Field Manual for the Collection of WaterQuality Data" (U.S. Geological Survey, variously dated).

Although periodic discrete sampling is useful for many monitoring purposes, it does not provide real-time data on which to base operational decisions to prevent degradation or treat the surface-water-supply reservoir for the city. Real-time data are needed to provide water suppliers with timely information to use in adjusting water-treatment strategies. Data from the discrete water-quality samples collected during 2005-9, in conjunction with the real-time streamflow data and data from the continuous in-stream water-quality monitors, provided the basis for developing regression equations for the estimation of concentrations of water-quality constituents of these source watersheds to Lake Houston.

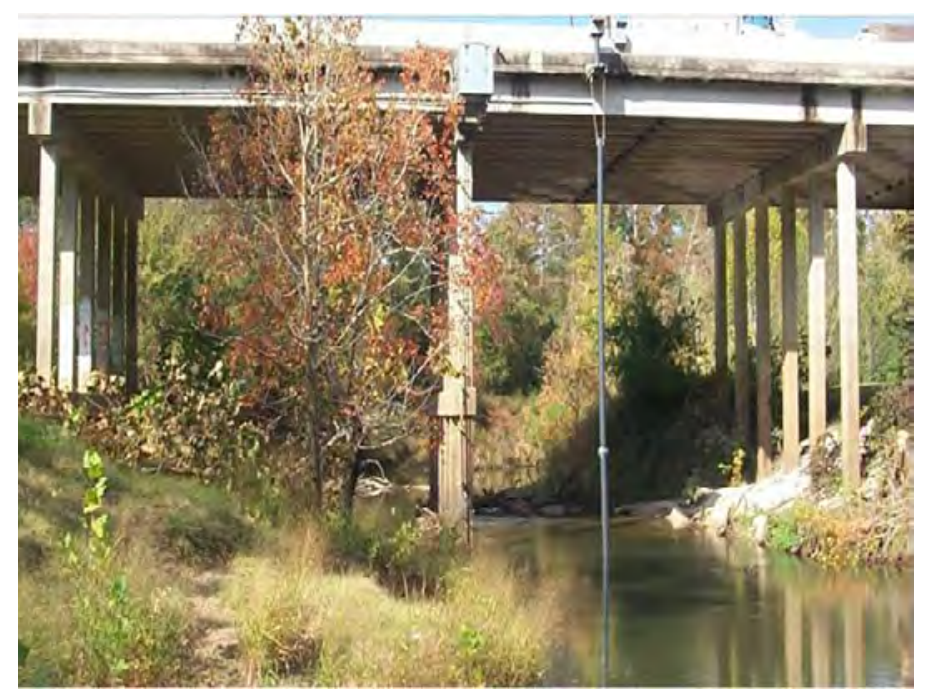

A continuous water-quality monitor is deployed within a "hangingwell" at U.S. Geological Survey streamflow-gaging 08070200 East Fork San Jacinto River near New Caney, Texas. 

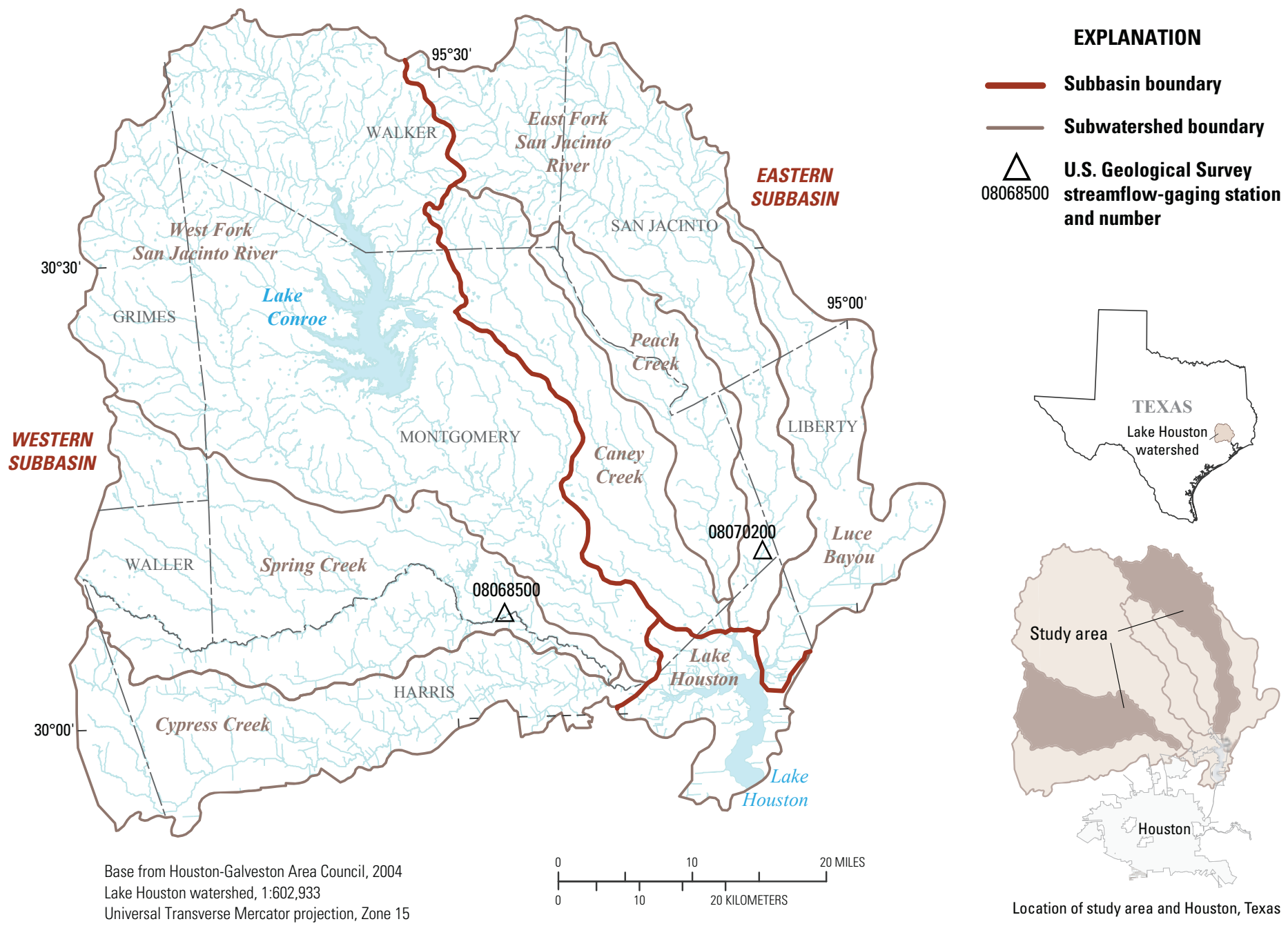

Location of study area and Houston, Texas

Figure 1. Lake Houston watershed and tributary subwatersheds and location of U.S. Geological Survey streamflow-gaging stations 08068500 Spring Creek near Spring, Texas, and 08070200 East Fork San Jacinto River near New Caney, Tex.

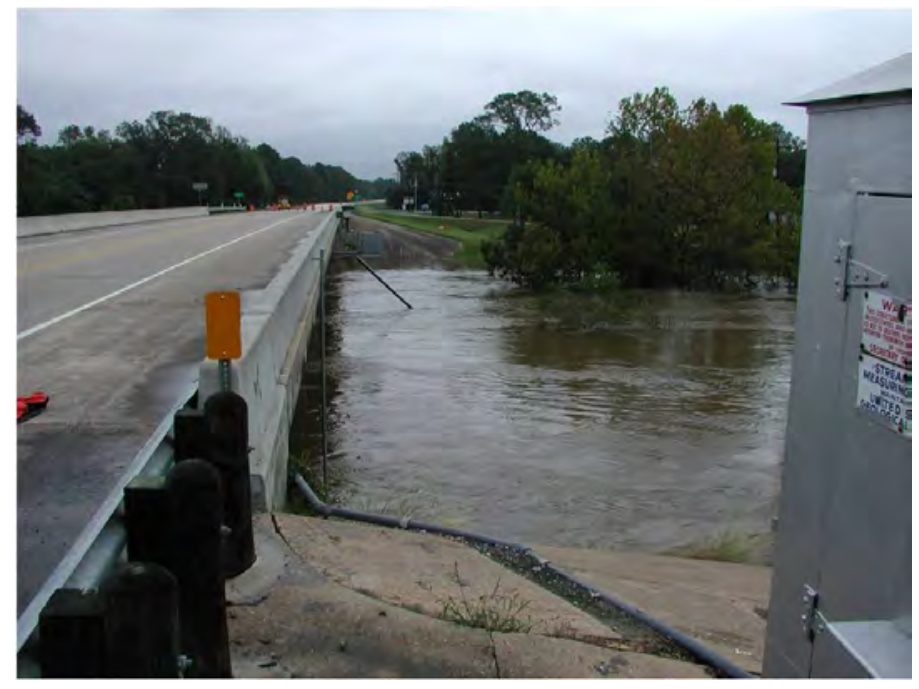

Example of a high-flow event at U.S. Geological Survey streamflow-gaging 08070200 East Fork San Jacinto River near New Caney, Texas.

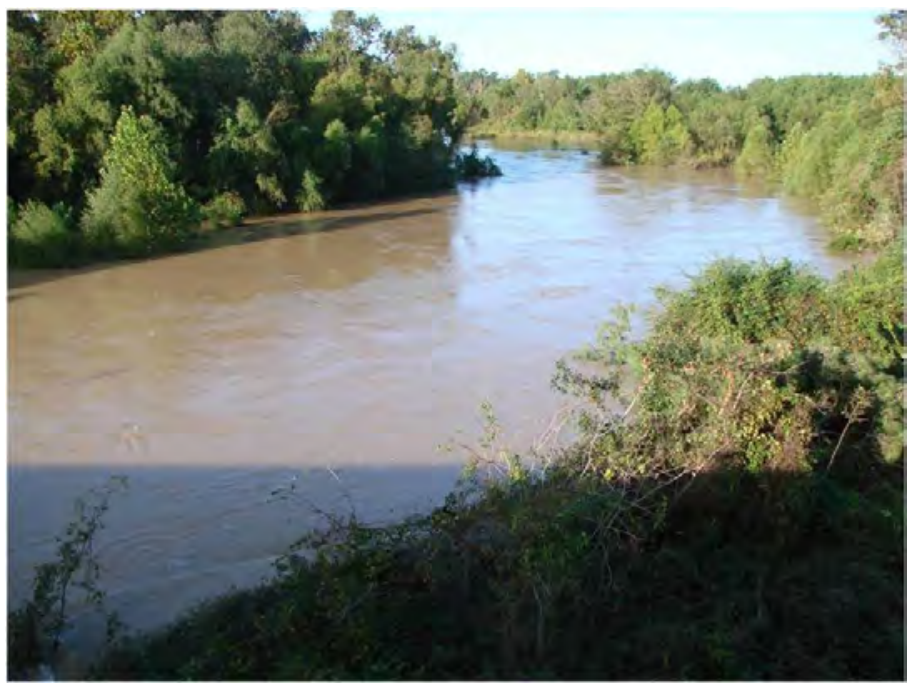

View of Spring Creek looking upstream from U.S. Geological Survey streamflow-gaging station 08068500 Spring Creek near Spring, Texas. 

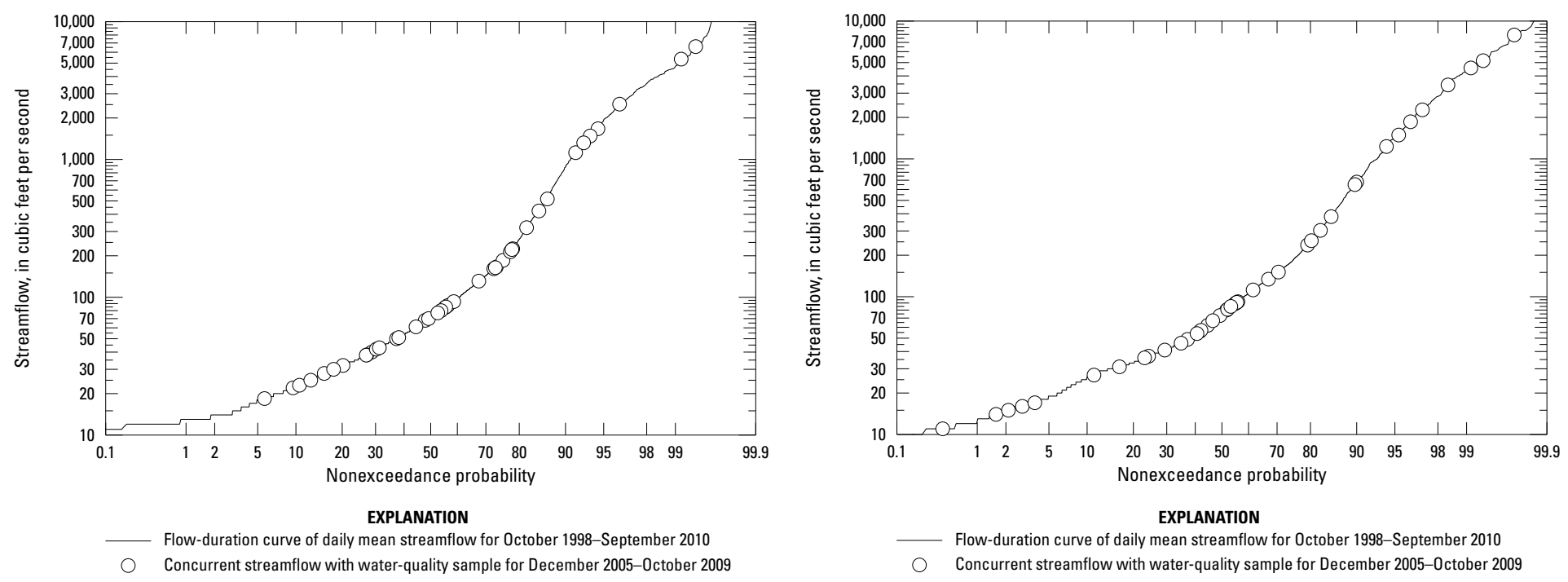

Figure 2. Flow duration curve and corresponding discrete water-quality samples, $(A)$ Spring Creek near Spring, Texas, and $(B)$ East Fork San Jacinto River near New Caney, Tex.

\section{Regression Analysis}

Explanatory variables provide data that serve as potential surrogates for estimating concentrations of selected constituents in a site-specific statistical regression analysis. The potential explanatory variables included discharge (streamflow), specific conductance, $\mathrm{pH}$, water temperature, turbidity, dissolved oxygen, and time (to account for seasonal variations inherent in some water-quality data). The response variables (the selected constituents) at each site were nitrite plus nitrate nitrogen, total phosphorus, total organic carbon, Escherichia coli, atrazine, and suspended sediment. Statistical regression facilitates corresponding estimates of uncertainty in the form of prediction intervals. Each regression equation potentially can be used to estimate concentrations of a given constituent in real time. The diagnostics used as indicators of general model reliability include the adjusted R-squared, the residual standard error, residual plots, and p-values.

In conjunction with estimated concentrations, constituent loads can be estimated by multiplying the estimated concentration by the corresponding streamflow and by applying the appropriate unit conversion factor.

\section{How Are the Data Used?}

Results from these regression models can be used to better understand fluctuations of concentration and loads during changing seasons and flow conditions and to assess waterquality conditions relative to total maximum daily load goals and water-quality standards. The information is also useful for evaluating loading characteristics, such as range and variability, and for determining effectiveness of best management practices (Rasmussen and others, 2008). With near real-time water-quality data for the tributaries (every 15 minutes), water managers and planners have tools to help identify potential effects of tributary inflows on the water quality of Lake Houston with sufficient alert time and can adjust operations at drinkingwater plants accordingly. In addition, over time the results of tributary water-quality monitoring will contribute to the broader understanding of watershed influences and the effects of those influences on Lake Houston as a drinking water and recreational resource.

\section{Conclusions}

- Continuously monitored streamflow and water-quality properties, in conjunction with regression models using data that serve as surrogates for other water-quality properties and constituents, can be used to estimate loads and frequency of occurrence for constituents lacking a continuous record in urban and rural watersheds.

- The real-time water-quality data provide information necessary for water managers and planners to prevent degradation or to adjust water-treatment strategies.

- The regression equations developed by using these methods are specific to the location where continuous monitoring and discrete sampling occurs.

- The general methods that were developed and documented could be applied to other tributaries to Lake Houston or scaled and modified to fit other project needs. 


\section{Real-Time Water-Quality Data}

As part of the USGS mission to describe water resources, the USGS provides access to the real-time water-quality data from this study (including streamflow, water temperature, specific conductance, $\mathrm{pH}$, dissolved oxygen, and turbidity) through WaterQualityWatch: http:// waterwatch.usgs.gov/wqwatch/. Data are available for more than 1,300 sites-from streams with watersheds as small as a few square miles to the watershed of the Mississippi River, which is more than $1,000,000$ square miles as it enters the Gulf of Mexico.

Additionally, the USGS includes the output of regression equations developed in this study on the National Real-Time Water Quality (NRTWQ) Web site: http://nrtwq.usgs.gov. The NRTWQ Web site conveniently provides estimated concentrations and loads for constituents, uncertainty values and probabilities for exceeding drinking water or recreational criteria, flow-duration curves, and historical hourly in-stream sensor measurements.

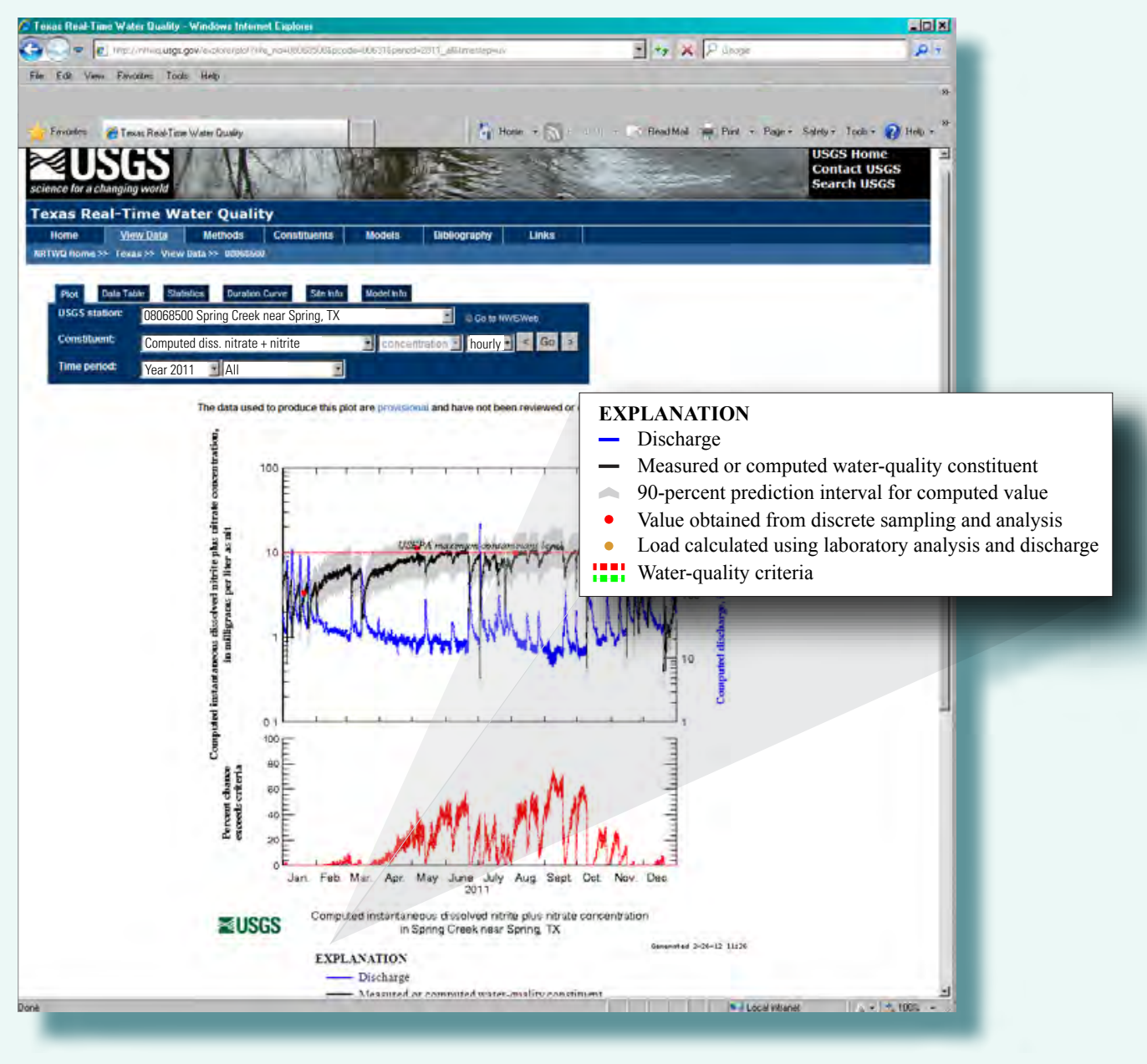

\section{Cited References}

City of Houston, 2011, Public Works and Engineering Drinking Water Operations: accessed March 2011, at http://www. publicworks.houstontx.gov/utilities/drinkingwater.html.

Harris-Galveston Subsidence District, 1999 [amended 2001], District regulatory plan: accessed April 22, 2008, at http://www. hgsubsidence.org/assets/pdfdocuments/HGRegPlan.pdf.

Kasmarek, M.C., Johnson, M.R., and Ramage, J.K., 2010, Waterlevel altitudes 2010 and water-level changes in the Chicot, Evangeline, and Jasper aquifers and compaction 1973-2009 in the Chicot and Evangeline aquifers, Houston-Galveston region, Texas: U.S. Geological Survey Scientific Investigations Map 3138, 17 p., 16 sheets, 1 appendix.

Rasmussen, T.J., Lee, C.J., and Ziegler, A.C., 2008, Estimation of constituent concentrations, loads, and yields in streams of Johnson County, northeast Kansas, using continuous waterquality monitoring and regression models, October 2002 through December 2006: U.S. Geological Survey Scientific Investigations Report 2008-5014, 103 p.
Texas State Data Center, 2011, 2009 total population estimates for Texas metropolitan statistical areas: Office of the State Demographer, Population Estimates and Projection Program, accessed March 16, 2011, at http://txsdc.utsa.edu/ tpepp/2009_txpopest_msa.php.

U.S. Geological Survey, variously dated, National field manual for the collection of water-quality data: U.S. Geological Survey Techniques of Water-Resources Investigations, book 9, chap. A1-A9 [variously paged]. (Also available at http://pubs.water. usgs.gov/twri9A.)

\section{By Michael T. Lee}

\section{For additional information, contact}

Director, USGS Texas Water Science Center

http://tx.usgs.gov/

gs-w-txpublic-info@usgs.gov 